\section{Hot Water Treatment Maintains Normal Ripening and Cell Wall Metabolism in Mango (Mangifera indica L.) Fruit}

\author{
Zhengke Zhang, Zhaoyin Gao, Min Li, Meijiao Hu ${ }^{1}$, Hui Gao, \\ Dongping Yang, and Bo Yang \\ Enviroment and Plant Protection Institute, Chinese Academy of Tropical \\ Agricultural Sciences, Danzhou 571737, China
}

Additional index words. chilling injury, mango, hot water treatment, HWT, pectic hydrolytic enzymes, polygalacturonase

\begin{abstract}
Tainong 1' mango fruit were treated with hot water for 10 minutes at $55^{\circ} \mathrm{C}$ and then stored at $5^{\circ} \mathrm{C}$ for 3 weeks. After removal from low-temperature storage, the effects of hot water treatment (HWT) on chilling injury (CI), ripening and cell wall metabolism during storage $\left(20^{\circ} \mathrm{C}, 5\right.$ days) were investigated. HWT reduced the $\mathrm{CI}$ development of the fruit as manifested by firmer texture, external browning, and fungal lesions. A more rapid ripening process, as indicated by changes in firmness, respiration rate, and ethylene production, occurred in heated fruit after exposure to low temperature as compared with non-heated fruit. At the same time, the cell wall components in heated fruit contained more water-soluble pectin and less 1,2-cyclohexylenedinitrilotetraactic acid (CDTA)-soluble pectin than those in non-heated fruit. HWT also maintained higher polygalacturonase [enzyme classification (EC) 3.2.1.15] and $\beta$-galactosidase (EC 3.2.1.23) activities as well as lower pectin methylesterase (EC 3.1.1.11) activity. In general, the changes of ripening and cell wall metabolism parameters in the heated fruit after low-temperature storage exhibited a comparable pattern to that of non-cold-stored fruit.
\end{abstract}

The sensitivity of mango (Mangifera indica $\mathrm{L}$.) fruit to $\mathrm{CI}$ when exposed to temperature below $13{ }^{\circ} \mathrm{C}$ limits the use of refrigeration to extend its storage and shelf life (Nair and Singh, 2003). CI symptoms of mango fruit are mainly manifested as skin browning or blackening, pitting on the peel, uneven ripening, reduced aroma and flavors, and increased susceptibility to fungal decay (Nair and Singh, 2003). The symptoms can become more severe after removal from chilling temperature (Ketsa et al., 2000). CI usually inhibits ethylene biosynthesis and production, leading to failure to ripen in mango fruit (Nair et al., 2004). Exogenous dip treatment with ethrel ( 50 to $500 \mathrm{mg} \cdot \mathrm{L}^{-1}$ ) effectively enhances the CI tolerance and improves the storage quality of mango fruit, suggesting that ethylene biosynthesis may be associated with the occurrence of CI (Nair and Singh, 2003). CI also causes damage to the cell wall of mango fruit, which

Received for publication 31 May 2012. Accepted for publication 1 Aug. 2012.

This research was supported by the Fundamental Research Funds for Environment and Plant Protection Institute, CATAS (1630042012009; 2012hzs1J011) and Special Fund for Agroscientific Research in the Public Interest, China (201203092-2).

We thank Dr. Jiankang Cao (China Agricultural University) for his helpful suggestions on the manuscript.

${ }^{1}$ To whom reprint requests should be addressed; e-mail humeijiao320@163.com.
2008; Zhou et al., 2006).

Postharvest heat treatments have been used to reduce the development of CI symptoms includes the loss of wall structural integrity metabolism involving in changes in pectin solubilization and degrading enzyme activ temperature induces oxidative stress when ve oxygen species are in excess spoilage and consequently results in $\mathrm{CI}$ in scavenging capacity, which causes membrane and improve the fruit quality during cold storage or after removal from low temperature in mangoes (Ketsa et al., 2000; McCollum et al., 1993) and other tropical or sub-tropical fruits such as avocado (Woolf et al., 1995), papaya (Huajaikaew et al., 2005), banana (Promyou et al., 2008) and citrus (Bassal and EI-Hamahmy, 2011). Heat air treatment $\left(38^{\circ} \mathrm{C}\right.$, $3 \mathrm{~d})$ may accelerate the softening that related to changes in pectic components and activities of polygalacturonase (PG), pectin methylesterase (PME), and $\beta$-galactosidases ( $\beta$-Gal) in 'Nam Dokmai' mango fruit during storage at ambient temperature $\left(25{ }^{\circ} \mathrm{C}\right)$ (Ketsa et al., 1998). However, to our knowledge, there has been little research into the effects of heat treatment on cell wall metabolism during storage at ambient temperature after CIinducing stress in mango fruit.

The objective of this study was to determine whether prestorage $\mathrm{HWT}\left(55^{\circ} \mathrm{C}, 10 \mathrm{~min}\right)$ could enhance tolerance to $\mathrm{CI}$ in mango fruit during ambient storage after 3 weeks of cold storage at a chilling temperature of $5{ }^{\circ} \mathrm{C}$. In addition, the study specifically addressed the effects of HWT on ripening and cell wall metabolism, including firmness, respiration rate, and ethylene production as well as pectic cell wall substances (water and CDTA-soluble pectins) and the activities of pectic hydrolytic enzymes (PG, PME, and $\beta-G a l)$.

\section{Materials and Methods}

Plant material and treatment. Mango ( $M$. indica L. cv. Tainong 1) fruit at the mature green stage were harvested from a commercial orchard in Baise City, China. Fruit were transported to the postharvest laboratory within $1 \mathrm{~d}$ of harvest. Fruit of uniform size and appearance and free from defects were selected and then divided randomly into three groups of 200 fruit. The first group was dipped in HWT at $55 \pm 1{ }^{\circ} \mathrm{C}$ for $10 \mathrm{~min}$. The second and third groups were dipped in tap water at $20 \pm 1{ }^{\circ} \mathrm{C}$ for $10 \mathrm{~min}$. After drying with paper towels, the first and second groups of fruit were placed in a cold room at $5^{\circ} \mathrm{C}$ and $90 \%$ to

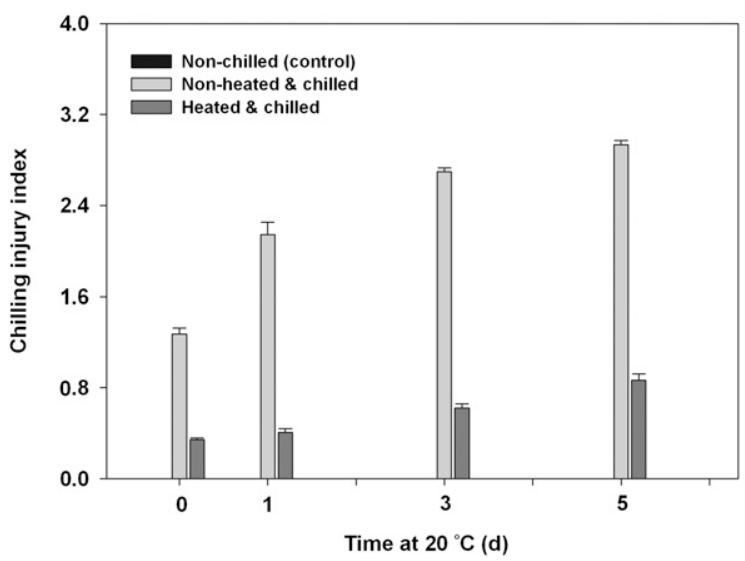

Fig. 1. Chilling injury (CI) index in non-heated $\left(20^{\circ} \mathrm{C}\right.$ water, $\left.10 \mathrm{~min}\right)$ and heated $\left(55^{\circ} \mathrm{C}\right.$ hot water, $\left.10 \mathrm{~min}\right)$ 'Tainong 1' mango fruit during storage at ambient temperature after 3 weeks of cold storage at $5{ }^{\circ} \mathrm{C}$. The fruit immersed in water $\left(20^{\circ} \mathrm{C}, 10 \mathrm{~min}\right)$ and then directly stored at ambient temperature served as control. Vertical bars represent means \pm SE of three replicates of 30 fruit for each treatment. 
$95 \%$ relative humidity for 3 weeks followed by transferring fruit to $20^{\circ} \mathrm{C}$ for $5 \mathrm{~d}$. The third group of fruit (non-chilled/control) was directly stored at $20^{\circ} \mathrm{C}$ for $5 \mathrm{~d}$ to allow normal ripening. During storage at $20{ }^{\circ} \mathrm{C}$, the $\mathrm{CI}$ severity of fruit from each treatment was monitored on Days $0,1,3$, and 5. The firmness, respiration rate, and ethylene production of fruit were measured daily, whereas the mesocarp tissues were sampled and frozen at $-80^{\circ} \mathrm{C}$ for later analysis of cell wall enzymes and components.

Chilling injury index. CI index was visually assessed from skin browning and surface lesion and expressed as a percentage of affected surface area in which $0=$ no injury (no browning or lesions), $1=$ slight (less than $25 \%$ of surface area), $2=$ moderate $(25 \%$ to $50 \%$ of surface area), $3=$ severe $(50 \%$ to $75 \%$ of surface area), and $4=$ extremely severe (greater than $75 \%$ of surface area). The CI index was determined with the formula: $\mathrm{CI}$ index $=\left(0 \times \mathrm{P}_{0}+1 \times \mathrm{P}_{1}+2 \times \mathrm{P}_{2}+3 \times\right.$ $\left.\mathrm{P}_{3}+4 \times \mathrm{P}_{4}\right) / \mathrm{N}$ in which $\mathrm{P}_{0}-\mathrm{P}_{4}=$ number of fruit in each CI scale and $\mathrm{N}=$ number of fruit with injury. There were three replicates of 30 fruit per treatment.

Fruit firmness. Firmness was determined using a pressure tester (Model FT327; Effegi, Milan, Italy) equipped with a 5-mm diameter probe. For each treatment, two measurements were carried out at two equidistant points on the equatorial axis of 10 fruit. Firmness was expressed as Newtons $(\mathrm{N})$.

Respiration rate and ethylene production. Five fruit from each treatment were placed individually in 2-L glass containers equipped with septa and sealed for $1 \mathrm{~h}$ at $20^{\circ} \mathrm{C}$. Respiration rate was determined with a $\mathrm{GXH}-$ 3010D IR $\mathrm{CO}_{2}$ analyzer (Huayun Inc., Beijing, China) equipped with an atmosphere-suction probe. Respiration rate as $\mathrm{CO}_{2}$ production was expressed in $\mu \mathrm{g} \cdot \mathrm{kg}^{-1} \cdot \mathrm{s}^{-1}$. Ethylene levels were analyzed by injecting a 1-mL sample of headspace into an Agilent-6890 gas chromatograph (Agilent Technologies Inc., Palo Alto, CA) fitted with a flame ionization detector. The oven, detector, and injector were operated at 100,150 , and $150^{\circ} \mathrm{C}$, respectively. The flow rates of carrier gas $\left(\mathrm{N}_{2}\right), \mathrm{H}_{2}$, and air were 50,50 , and $250 \mathrm{~mL} \cdot \mathrm{min}^{-1}$, respectively. Ethylene production was expressed as $\mathrm{ng} \cdot \mathrm{kg}^{-1} \cdot \mathrm{s}^{-1}$.

Pectin extraction and analysis. Ten grams of mango mesocarp (three replicates of $10 \mathrm{~g}$ from three fruit for each treatment) were used for ethanol-soluble-solids (EIS) preparation. Preparation and extraction of EIS were performed according to the method of Jeong et al. (2002). Water- and CDTA-soluble pectins were extracted from $30 \mathrm{mg}$ EIS incubated in $15 \mathrm{~mL}$ of distilled water at $34{ }^{\circ} \mathrm{C}$ for $4 \mathrm{~h}$, filtered, and then quantified with the hydroxydiphenyl assay (Blumenkrantz and AsboeHansen, 1973) using galacturonic acid as a standard. Contents of water- and CDTAsoluble pectins are expressed as grams galacturonic acid equivalents per kilogram EIS $\left(\mathrm{g} \cdot \mathrm{kg}^{-1}\right)$.

Measurement of cell wall enzyme activities. The activities of PG, PME, and $\beta$-Gal were measured in cell-free protein extracts from $10 \mathrm{~g}$ (three replicates of $10 \mathrm{~g}$ samples from three fruit) of mango fruit flesh following the methods by Huber and O'Donoghue (1993).

Reaction mixtures for the determination of PG activity consisted of $0.1 \mathrm{~mL}$ of the cellfree protein extract and $0.5 \mathrm{~mL}(1 \mathrm{mg})$ of polygalacturonic acid (Sigma-Aldrich Co. LLC., St. Louis, MO) in $40 \mathrm{~mm}$ Na-acetate
(pH 5.5) containing $0.1 \mathrm{M} \mathrm{NaCl}$. After the samples were incubated for $2 \mathrm{~h}$ at $34^{\circ} \mathrm{C}$, PG activity was measured using the method of Milner and Avigad (1967) and expressed as mmol galacturonic acid equivalents generated per mass of protein per second $\left(\mathrm{mmol} \cdot \mathrm{kg}^{-1} \cdot \mathrm{s}^{-1}\right)$.

$\beta$-Gal activity was measured using the method of Pharr et al. (1976) with some modifications by Jeong et al. (2002). $p-\mathrm{NO}_{2}$-phenyl

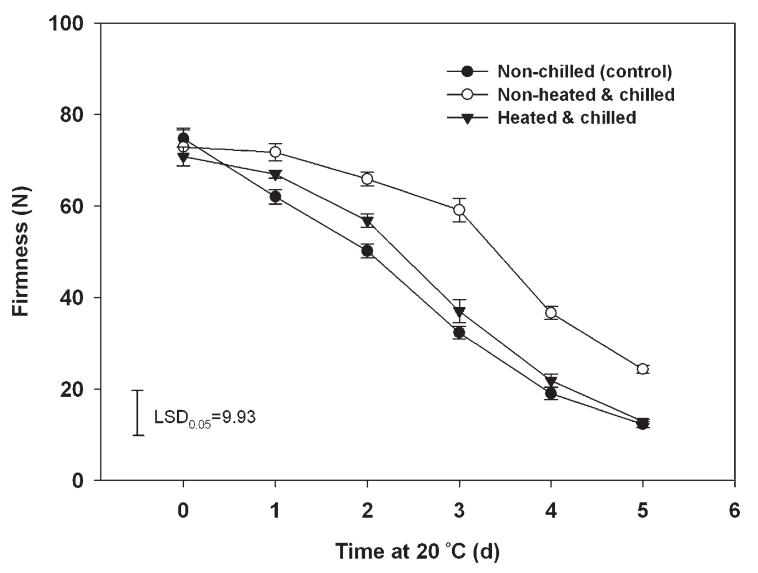

Fig. 2. Firmness in non-heated $\left(20^{\circ} \mathrm{C}\right.$ water, $\left.10 \mathrm{~min}\right)$ and heated $\left(55^{\circ} \mathrm{C}\right.$ hot water, $\left.10 \mathrm{~min}\right)$ 'Tainong 1 ' mango fruit during storage at ambient temperature after 3 weeks of cold storage at $5{ }^{\circ} \mathrm{C}$. The fruit immersed in water $\left(20^{\circ} \mathrm{C}, 10 \mathrm{~min}\right)$ and then directly stored at ambient temperature served as control. Vertical bars represent means \pm SE of 10 individual fruit for each treatment.
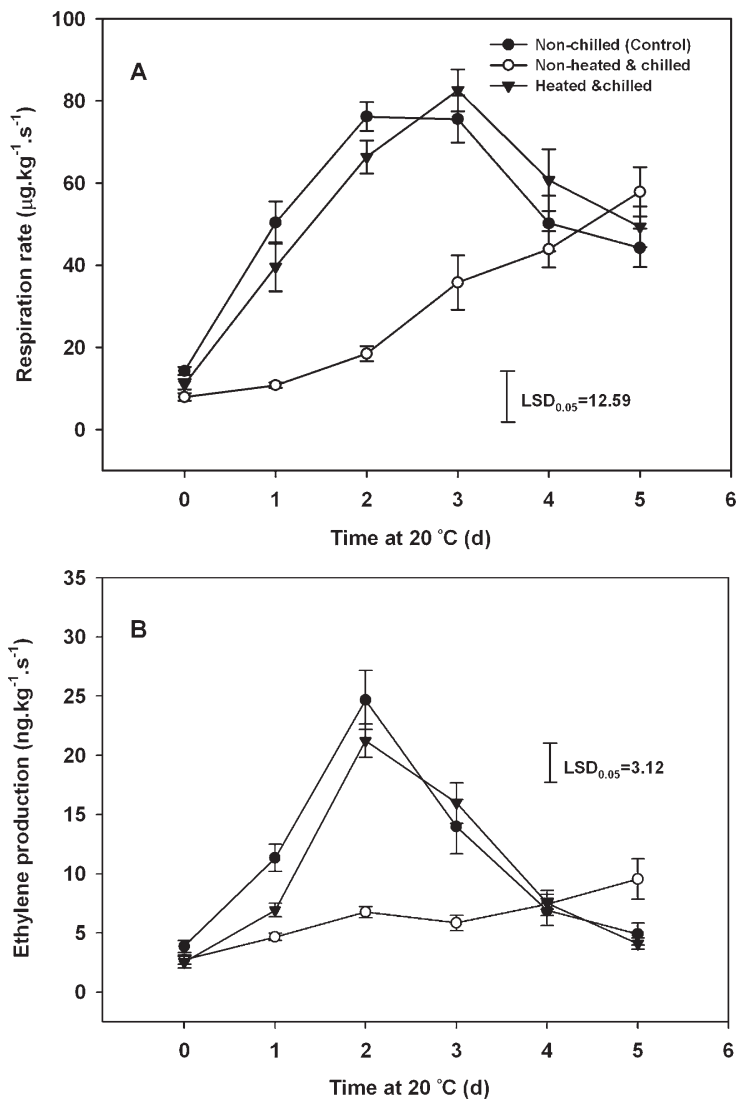

Fig. 3. Respiration rate (A) and ethylene production $(\mathbf{B})$ in non-heated $\left(20^{\circ} \mathrm{C}\right.$ water, $\left.10 \mathrm{~min}\right)$ and heated $\left(55^{\circ} \mathrm{C}\right.$ hot water, $10 \mathrm{~min}$ ) 'Tainong $1^{\text {' }}$ mango fruit during storage at ambient temperature after 3 weeks of cold storage at $5{ }^{\circ} \mathrm{C}$. The fruit immersed in water $\left(20^{\circ} \mathrm{C}, 10 \mathrm{~min}\right)$ and then directly stored at ambient temperature served as control. Vertical bars represent means \pm SE of five individual fruit for each treatment. 
$\beta$-D-galactopyranosides (Sigma-Aldrich Co. LLC.) were used as substrates, which were prepared at $2 \mathrm{~g} \cdot \mathrm{L}^{-1}$ in $0.1 \mathrm{M} \mathrm{NaOAc}(\mathrm{pH} 5.2)$. In a $10-\mathrm{mL}$ test tube, $1.5 \mathrm{~mL}$ cell-free protein extract was added to $1.5 \mathrm{~mL}$ of substrate, and the reaction mixture was incubated at $37^{\circ} \mathrm{C}$ for $1 \mathrm{~h}$. The release of $p-\mathrm{NO}_{2}$-phenol was measured at $400 \mathrm{~nm}$ absorbance. The activity was expressed as mmol $\mathrm{NO}_{2}$-phenol equivalents released per kilogram protein per second $\left(\mathrm{mmol} \cdot \mathrm{kg}^{-1} \cdot \mathrm{s}^{-1}\right)$. The $\mathrm{NO}_{2}$-phenol concentration was determined using free $\mathrm{NO}_{2}$-phenol (Sigma-Aldrich Co. LLC.).

PME was measured according to the method of Hagerman and Austin (1986) with some modifications. A $0.5 \%(\mathrm{w} / \mathrm{v})$ solution of citrus pectin (Sigma-Aldrich Co. LLC.) was prepared in $0.1 \mathrm{M} \mathrm{NaCl}$ and adjusted to $\mathrm{pH}$ 7.5 with dilute $\mathrm{NaOH}$. A $0.01 \%$ (w/v) solution of bromothymol blue was prepared in $30 \mathrm{~mm}$ potassium phosphate, $\mathrm{pH}$ 7.5. In a cuvette, $2.0 \mathrm{~mL}$ of the $0.5 \%$ citrus pectin was mixed with $0.15 \mathrm{~mL}$ of bromothymol blue solution and $0.8 \mathrm{~mL}$ of water. The reaction was initiated by adding $50 \mu \mathrm{L}$ of the cellfree protein extract, and the decrease in $A_{620}$ was recorded. PME activity was expressed as $\Delta A_{620}$ per milligram protein per second $\left(\Delta A_{620} \mathrm{mg}^{-1} \cdot \mathrm{s}^{-1}\right)$.

Protein concentrations were determined according to the method of Bradford (1976) using bovine serum albumin as a standard.

Statistical analysis. Data were subjected to analysis of variance (ANOVA) using SAS statistical software (Version 8; SAS Institute, Cary, NC). Fisher's least significant differences $(P=0.05)$ were determined to compare differences between means following a significant ANOVA effect. Data were presented as the mean \pm SEM.

\section{Results}

Chilling injury. Non-cold-stored fruit did not show any CI symptoms during storage at $20^{\circ} \mathrm{C}$. Fruit developed CI during 3 -week cold storage at $5{ }^{\circ} \mathrm{C}$ (Fig. 1). The CI severity of heated fruit was lower than that in non-heated fruit at the end of cold storage $(0 \mathrm{~d})$. CI gradually increased in severity during storage at $20{ }^{\circ} \mathrm{C}$ after chilling stress irrespective of the treatments. HWT strongly suppressed the development of CI over $5 \mathrm{~d}$ at $20^{\circ} \mathrm{C}$, during which the CI index of heated fruit averaged $77 \%$ lower than that of control fruit (Fig. 1).

Firmness. The firmness in non-cold-stored fruit declined rapidly from $74.8 \pm 11.9$ to $12.3 \pm 0.7 \mathrm{~N}$ after $5 \mathrm{~d}$ of storage at $20{ }^{\circ} \mathrm{C}$ (Fig. 2). The fruit firmness, irrespective of heated or non-heated treatment, did not significantly change during cold storage (Fig. 2). On removal from cold storage to $20^{\circ} \mathrm{C}$, nonheated fruit maintained a higher firmness within the first $3 \mathrm{~d}$ and thereafter softened sharply until the end of storage. Heated fruit exhibited little change in firmness within $1 \mathrm{~d}$ of storage at $20^{\circ} \mathrm{C}$, comparable to that in nonheated fruit. After $1 \mathrm{~d}$, the softening trend of heated fruit diverged from non-heated fruit (Fig. 2). Throughout the storage at $20^{\circ} \mathrm{C}$, the firmness of heated fruit after 3 -week cold storage was similar to that of non-chilled fruit (Fig. 2).

Respiration rate and ethylene production. Non-cold-stored fruit showed a typical respiration climacteric pattern during storage at $20{ }^{\circ} \mathrm{C}$ with the respiration rate rapidly increasing from an initial value of $14.3 \pm 1.0$ to maximum of $76.2 \pm 3.5 \mu \mathrm{g} \cdot \mathrm{kg}^{-1} \cdot \mathrm{s}^{-1}$ at $2 \mathrm{~d}$ of storage and then steadily declining as the fruit ripened (Fig. 3A). Respiration rates in heated and non-heated fruit did not change after 3 weeks of cold storage at $5{ }^{\circ} \mathrm{C}(0 \mathrm{~d})$. During storage at $20{ }^{\circ} \mathrm{C}$, non-heated fruit exhibited a gradual and slow increase in respiration rate, whereas a normal respiration mode was observed in heated fruit in which the respiratory peak was only delayed by $1 \mathrm{~d}$ as compared with non-cold-stored fruit (Fig. 3A).

Ethylene production in non-cold-stored mango fruit sharply increased from an initial rate of $3.9 \pm 0.5 \mathrm{ng} \cdot \mathrm{kg}^{-1} \cdot \mathrm{s}^{-1}$ to climacteric maximum of $24.7 \pm 2.5 \mathrm{ng} \cdot \mathrm{kg}^{-1} \cdot \mathrm{s}^{-1}$ within $2 \mathrm{~d}$ of storage at $20^{\circ} \mathrm{C}$ followed by a continuous decline with further ripening (Fig. 3B). During 3-week cold storage at $5{ }^{\circ} \mathrm{C}$, the ethylene production in heated and non-heated fruit was similar. After transfer to $20^{\circ} \mathrm{C}$, a slight increase of ethylene production was found in non-heated fruit. However, a similar changing pattern in ethylene production was observed between heated fruit after cold storage and non-cold-stored fruit (Fig. 3B).

Contents of water and 1,2-cyclohexylenedinitrilotetraactic acid-soluble pectin. Noncold-stored mango fruit showed an approximate $270 \%$ increase in water-soluble pectin (WSP) content over ambient storage (Fig. 4A). During storage at $20^{\circ} \mathrm{C}$, the WSP content in nonheated fruit after cold storage increased more slowly than that in non-cold-stored fruit (Fig. 4A). Comparatively, the heated fruit after lowtemperature storage exhibited a similar changing pattern of WSP to non-cold-stored fruit (Fig. 4A).

The content of CDTA-soluble pectin (CSP) in non-cold-stored fruit steadily increased throughout the storage at $20{ }^{\circ} \mathrm{C}$ (Fig. 4B). The content of CSP in both non-heated and heated fruit increased after cold storage, but a greater increase of CSP content occurred in the former. After removal to ambient storage, non-heated fruit showed a more rapid increase of CSP content than those in heated and noncold-stored fruit, although CSP contents in non-heated and heated fruit were usually similar (Fig. 4B).

Activities of polygalacturonase, $\beta$-galactosidases, and pectin methylesterase. PG activity in non-cold-stored fruit rapidly increased to maximum within the first $3 \mathrm{~d}$ of ripening at
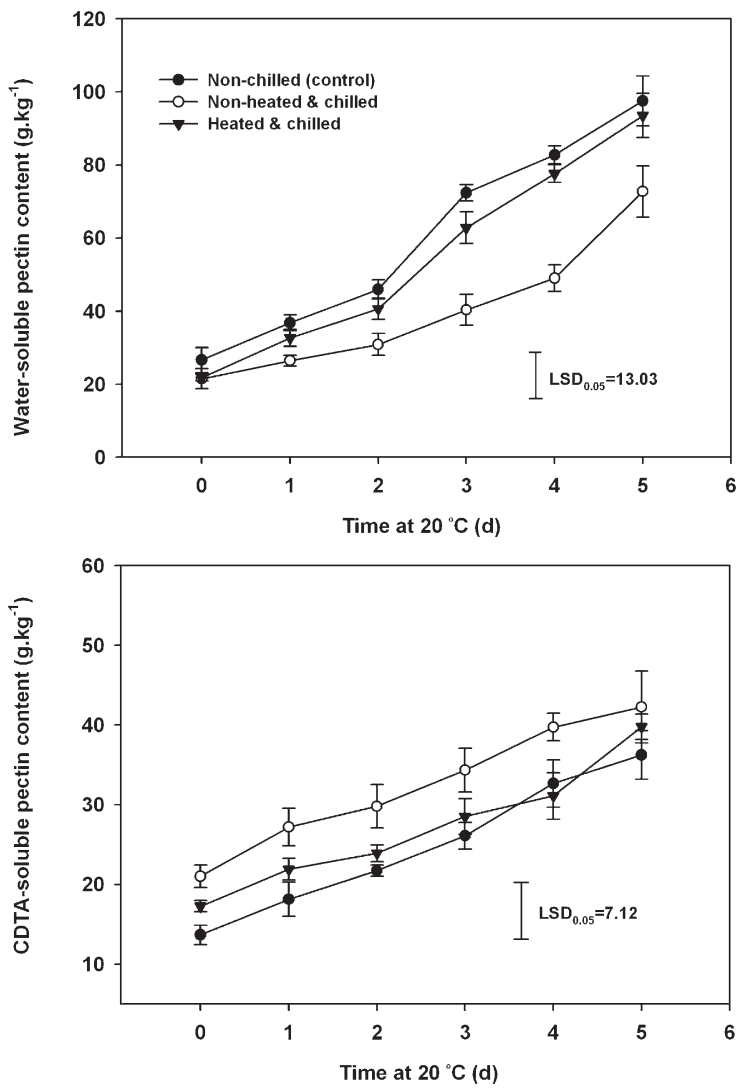

Fig. 4. Water (A) and 1,2-cyclohexylenedinitrilotetraactic acid (CDTA)-soluble (B) pectin contents in non-heated $\left(20^{\circ} \mathrm{C}\right.$ water, $\left.10 \mathrm{~min}\right)$ and heated $\left(55^{\circ} \mathrm{C}\right.$ hot water, $\left.10 \mathrm{~min}\right)$ 'Tainong 1 ' mango fruit during storage at ambient temperature after 3 weeks of cold storage at $5{ }^{\circ} \mathrm{C}$. The fruit immersed in water $\left(20^{\circ} \mathrm{C}, 10 \mathrm{~min}\right)$ and then directly stored at ambient temperature served as control. Vertical bars represent means \pm SE of three replicates for each treatment. 

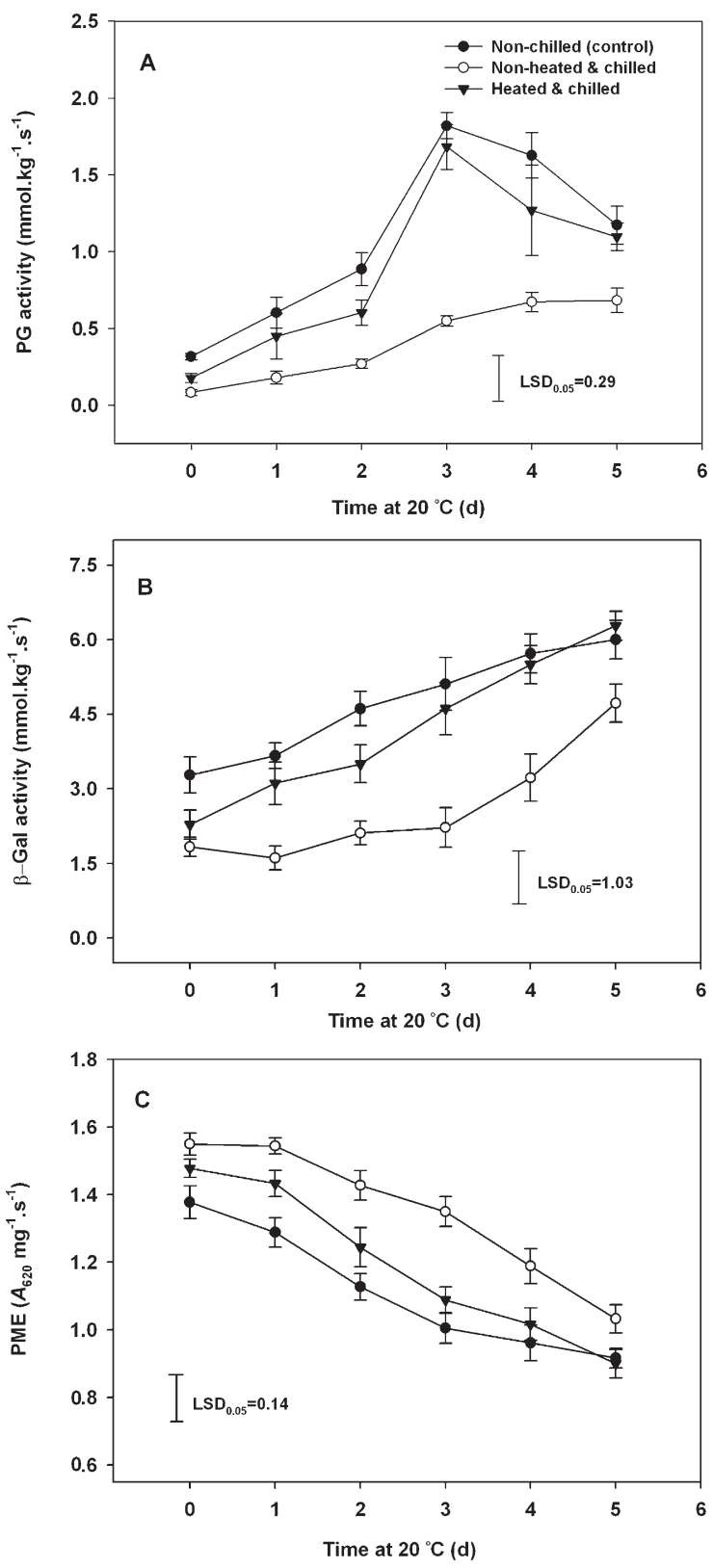

Fig. 5. Polygalacturonase (PG) (A), $\beta$-galactosidase ( $\beta$-gal) (B), and pectin methylesterase (PME) (C) activities in non-heated $\left(20^{\circ} \mathrm{C}\right.$ water, $\left.10 \mathrm{~min}\right)$ and heated $\left(55^{\circ} \mathrm{C}\right.$ hot water, $\left.10 \mathrm{~min}\right)$ 'Tainong 1 ' mango fruit during storage at ambient temperature after 3 weeks of cold storage at $5{ }^{\circ} \mathrm{C}$. The fruit immersed in water $\left(20^{\circ} \mathrm{C}, 10 \mathrm{~min}\right)$ and then directly stored at ambient temperature served as control. Vertical bars represent means \pm SE of three replicates for each treatment.

$20{ }^{\circ} \mathrm{C}$ followed by a steady decline over remainder of storage (Fig. $5 \mathrm{~A}$ ). During storage at $20^{\circ} \mathrm{C}$ after 3 weeks of cold storage, the PG activity in non-heated fruit slightly increased, whereas that in heated fruit increased to a much greater extent within $4 \mathrm{~d}$ and then gradually decreased to a similar level as that found in non-chilled fruit at $5 \mathrm{~d}$ (Fig. 5A).

$\beta$-Gal activity in non-chilled fruit gradually increased during fruit ripening at $20^{\circ} \mathrm{C}$ (Fig. 5B). $\beta$-Gal activity in both heated and non-heated fruit markedly reduced after removal from 3-week cold storage (Fig. 5B). The level of $\beta$-Gal in non-heated fruit remained unchanged within the initial $3 \mathrm{~d}$ of storage at $20^{\circ} \mathrm{C}$ and then rapidly increased.
By contrast, $\beta$-Gal activity in heated fruit increased with a greater rate throughout the storage at $20{ }^{\circ} \mathrm{C}$, and it showed no difference in activity as compared with non-coldstored fruit during the last $3 \mathrm{~d}$ of storage (Fig. 5B).

PME activity in non-heated and heated fruit increased after 3 weeks of cold storage, but a greater extent was observed in the former (Fig. 5C). All fruit regardless of treatments exhibited a steady decline in PME activity during storage at $20{ }^{\circ} \mathrm{C}$, whereas activity in non-cold-stored fruit and heated fruit after chilling stress was lower than that in nonheated fruit throughout the storage at $20{ }^{\circ} \mathrm{C}$ (Fig. 5C).

\section{Discussion}

HWT $\left(55^{\circ} \mathrm{C}, 10 \mathrm{~min}\right.$ ) effectively reduced the $\mathrm{CI}$ index of 'Tainong 1' mango fruit during storage at ambient temperature $\left(20^{\circ} \mathrm{C}\right)$ for up to $5 \mathrm{~d}$ after 3 weeks of cold storage at $5{ }^{\circ} \mathrm{C}$. Similarly, Ketsa et al. (2000) reported that heat air treatment $\left(38^{\circ} \mathrm{C}, 3 \mathrm{~d}\right)$ strongly suppresses the developments of CI and disease in 'Nam Dokmai' mangoes fruit during ripening at $25{ }^{\circ} \mathrm{C}$ for $6 \mathrm{~d}$ after 3 weeks of cold storage at $4{ }^{\circ} \mathrm{C}$. Yimyong et al. (2011) noted that a slight $\mathrm{CI}$ symptom, manifested by visible shriveling, was reduced by prestorage HWT $\left(50{ }^{\circ} \mathrm{C}, 10 \mathrm{~min}\right)$ during ripening at ambient temperature after the transfer from cold storage at 8 or $12{ }^{\circ} \mathrm{C}$ in 'Okrong' mango fruit. Minor symptoms in the study of Yimyong et al. (2011) might be the result of the use of a higher storage temperature of 8 and $12{ }^{\circ} \mathrm{C}$.

Suppressed softening and delayed respiration and ethylene production during ambient storage at $20{ }^{\circ} \mathrm{C}$ were observed in non-heated fruit after exposure to CI-inducing temperature (Figs. 2 and 3). A similar result for ripening retention after low-temperature storage was also previously obtained in 'Nam Dokmai' (Ketsa et al., 1999) and 'Zill' (Han et al., 2006) mango fruit and other fruit including plum (Manganaris et al., 2008) and tomato (Rugkong et al., 2010), which correlates to the inhibition of ethylene biosynthesis and the alternation of receptor gene expression involving in ethylene signal transduction in chilled fruit (Nair et al., 2004; Rugkong et al., 2011). Furthermore, in the current study, during storage at $20^{\circ} \mathrm{C}$, the heated fruit after cold stress showed similar patterns of softening, respiration, and ethylene evolution to those found for the non-cold-stored fruit, which suggests that the alleviation of CI resulting from HWT may be related to normal ripening in mango fruit. The data presented here also provide additional evidence that suppression of ethylene biosynthesis and physiological action may be partially involved in CI development of mango fruit, as has been demonstrated by Nair and Singh (2003) and Nair et al. (2004). By contrast, little recovery of ethylene production was found in heated 'Okrong' mango fruit after removing them from 8 or $12{ }^{\circ} \mathrm{C}$ into ambient temperature (Yimyong et al., 2011). Zaharah and Singh (2011) noted that nitric oxide treatment reduced CI severity while suppressing ethylene production in 'Kensington Pride' mango fruit. These inconsistent conclusions suggest that the relationship between ethylene and CI is complex (Watkins, 2006).

It has been well known that fruit softening involves depolymerization and solubilization of cell wall components including matrix polysaccharides (hemicellulose and pectins) (Brummell and Harpster, 2001). The final hydrolysis and breakdown of pectic cell wall components result from the action of cell wall hydrolases, including PG, PME, and $\beta-G a l$, as has been found in various mango cultivars (Ali et al., 1995, 2004; Chourasia et al., 2006; Zheng et al., 2012). In the present study, 
during storage at $20{ }^{\circ} \mathrm{C}$, the content of WSP in non-heated mango fruit after cold storage showed a slight increase but to a lesser extent compared with that in non-cold-stored fruit. Reduced WSP in chilled fruit might directly result in the retardation of softening, which is consistent with the previous studies as observed in 'Nam Dokmai' mango fruit (Ketsa et al., 1999) and other fruit such as peaches (Brummell et al., 2004), plum (Manganaris et al., 2008) and tomato (Rugkong et al., 2010). Furthermore, it is suggested that reduction degree in pectin solubilization of chilled fruit would presumably depend on the extent of CI (Almeida and Huber, 2008; Rugkong et al., 2010). In non-heated mango fruit after exposure to low temperature, $\mathrm{PG}$ and $\beta$-Gal activities also showed extremely less increase than those in non-cold-stored fruit (Fig. 5A-B), which is in agreement with the result of a previous study on 'Nam Dokmai' mango fruit (Ketsa et al., 1999). Reduction extent of $P G$ activity and $P G$ gene expression may be associated with the increasing time period of exposure to chilling temperature in mango (Ketsa et al., 1999) and tomato (Rugkong et al., 2010, 2011), although no significant effect of low temperature on $\beta$-Gal activity was observed in tomato (Rugkong et al., 2010). The effect of low temperature on PME activity has shown a difference depending on the cultivar, degree of low temperature, and other unknown factors. In the present work, PME activity was increased by cold storage, in which the highest activity occurred in non-heated fruit after cold storage. Cold-induced enhancement in PME activity has also been reported in 'Nam Dokmai' mango (Ketsa et al., 1999), tomato (Marangoni et al., 1995), and avocado (Gertman and Fuchs, 1974), suggesting that increased PME activity in these fruit may be related to the development of CI. Similar to the report of Ketsa et al. (1999), the enhanced PME activity in response to low temperature could also contribute to the increase in CSP content (Fig. 4B). In this case, the methyl group may be removed from galacturonic acid by PME action so that the pectin molecules have more binding sites to be solubilized and extracted by chelators such as CDTA and oxalate.

In contrast to non-heated fruit, the cell wall metabolism pattern in heated fruit after cold storage was overall similar to those found for non-cold-stored fruit, as indicated by changes of PG, $\beta$-Gal, and PME activities as well as water/CDTA-soluble pectin contents. These results suggest that the maintenance of cell metabolism at a normal level by HWT may be involved in the reduction of CI in mango fruit. In a recent study on 'Okrong' mango fruit, HWT enhanced the increase in transcripts of some cell wall hydrolase genes including $\beta$-Gal and pectate lyase during cold storage but which did not result in a difference in fruit softening as compared with non-heated fruit (Yimyong et al., 2011). Ketsa et al. (1998) reported that heat air treatment accelerated the softening while inhibiting the increase of PG and enhancing the increase of
$\beta$-Gal in 'Nam Dokmai' mango fruit during ripening in fruit stored under ambient temperature. The authors suggest that the softening of mango fruit may be more closely related to changes in $\beta$-Gal than in PG. However, Zheng et al. (2012) demonstrated that the softening of 'Zill' mango fruit may be at least partially attributed to the involvement of PG that was suppressed by oxalic acid treatment during storage at room temperature. These findings indicate that factors including specific mango cultivar, storage condition (stress or nonstress), postharvest treatments, and posttranscriptional regulation of pectic hydrolases may have contributed to the different changes of cell wall metabolism in mango fruit.

In conclusion, our results showed that HWT at $55{ }^{\circ} \mathrm{C}$ for $10 \mathrm{~min}$ effectively enhanced chilling tolerance in 'Tainong 1' mango fruit during ambient storage after exposure to low temperature. The reduction of CI by HWT is possibly related to its effect on maintaining normal ripening and cell wall metabolism.

\section{Literature Cited}

Ali, Z.M., H. Armugam, and H. Lazan. 1995. $\beta$-Galactosidase and its significance in ripening mango fruit. Phytochemistry 38:1109-1114.

Ali, Z.M., L.H. Chin, and H. Lazan. 2004. A comparative study on wall degrading enzymes, pectin modifications and softening during ripening of selected tropical fruits. Plant Sci. 167:317-327.

Almeida, D.P.F. and D.J. Huber. 2008. In vivo pectin solubility in ripening and chill-injured tomato fruit. Plant Sci. 174:174-182.

Bassal, M. and M. El-Hamahmy. 2011. Hot water dip and preconditioning treatments to reduce chilling injury and maintain postharvest quality of Navel and Valencia oranges during cold quarantine. Postharvest Biol. Technol. 60:186191.

Blumenkrantz, N. and G. Asboe-Hansen. 1973. New method for quantitative determination for uronic acids. Anal. Biochem. 54:448-449.

Bradford, M.M. 1976. A rapid and sensitive method for quantitation of microgram quantities of protein utilizing the principle of protein-dyebinding. Anal. Biochem. 72:248-254.

Brummell, D.A. and M.H. Harpster. 2001. Cell wall metabolism in fruit softening and quality and its manipulation in transgenic plants. Plant Mol. Biol. 47:311-339.

Brummell, D.A., V. Dal Cin, S. Lurie, C.H. Crisosto, and J.M. Labavitch. 2004. Cell wall metabolism during the development of chilling injury in cold-stored peach fruit: Association of mealiness with arrested disassembly of cell wall pectins. J. Expt. Bot. 55:20412052.

Chourasia, A., V.A. Sane, and P. Nath. 2006. Differential expression of pectatelyase during ethylene-induced postharvest softening of mango (Mangifera indica var. Dashehari). Physiol. Plant. 128:546-555.

Ding, Z.S., S.P. Tian, X.L. Zheng, Z.W. Zhou, and Y. Xu. 2007. Responses of reactive oxygen metabolism and quality in mango fruit to exogenous oxalic acid or salicylic acid under chilling temperature stress. Physiol. Plant. 130: $112-121$.

Gertman, A.E. and Y. Fuchs. 1974. Changes in pectinmethyl-esterase (PME) activity caused by ethylene applied at different temperature. Plant Cell Physiol. 15:501-505.
Hagerman, A.E. and P.J. Austin. 1986. Continuous spectrophotometric assay for plant pectin methyl esterase. J. Agr. Food Chem. 34:440444.

Han, J., S.P. Tian, X.H. Meng, and Z.S. Ding. 2006. Response of physiologic metabolism and cell structures in mango fruit to exogenous methyl salicylate under low-temperature stress. Physiol. Plant. 128:122-133.

Huajaikaew, L., A. Uthairatanakij, S. Kanlayanarat, and H. Gemma. 2005. Effect of heat treatment on antioxidants in papaya fruit stored at low temperature. Acta Hort. 682:1063-1068.

Huber, D.J. and E.M. O'Donoghue. 1993. Polyuronides in avocado (Persea americana) and tomato (Lycopersicon esculentum) exhibit markedly different patterns of molecular mass downshifts during ripening. Plant Physiol. 102:473-480

Jeong, J., D.J. Huber, and S.A. Sargent. 2002. Influence of 1-methylcyclopropene (1-MCP) on ripening and cell wall matrix polysaccharides of avocado. Postharvest Biol. Technol. 25:241-256.

Ketsa, S., S. Chidtragool, J.D. Klein, and S. Lurie 1998. Effect of heat treatment on changes in softening, pectic substances and activities of polygalacturonase, pectinesterase and $\beta$-galactosidases of ripening mango. J. Plant Physiol. 153:457461.

Ketsa, S., S. Chidtragool, J.D. Klein, and S. Lurie. 1999. Firmness, pectin components and cell wall hydrolases of mango fruit following lowtemperature stress. J. Hort. Sci. Biotechnol. 74: 685-689.

Ketsa, S., S. Chidtragool, and S. Lurie. 2000. Prestorage heat treatment and postharvest quality of mango fruit. HortScience 35:247249.

Manganaris, G.A., A.R. Vicente, C.H. Crisosto, and J.M. Labavitch. 2008. Cell wall modifications in chilling-injured plum fruit (Prunus salicina). Postharvest Biol. Technol. 48:7783.

Marangoni, A.G., R.L. Jackman, and D.W. Stanley. 1995. Chilling-associated softening of tomato fruit is related to increased pectin methylesterase activity. J. Food Sci. 60:12771281.

McCollum, T.G., S. D'Aquino, and R.E. McDonald. 1993. Heat treatment inhibits mango chilling injury. HortScience 28:197-198.

Milner, Y. and G. Avigad. 1967. A copper reagent for the determination of hexuronic acids and certain ketohexoses. Carbohydr. Res. 4:359361.

Nair, S. and Z. Singh. 2003. Pre-storage ethrel dip reduces chilling injury, enhances respiration rate, ethylene production and improves fruit quality of 'Kensington Pride' mango. Food Agr. Environ. 1:93-97.

Nair, S., Z. Singh, and S.C. Tan. 2004. Chilling injury in relation to ethylene biosynthesis in 'Kensingto Pride' mango fruit. J. Hort. Sci. Biotechnol. 79:82-90.

Pharr, D.M., H.N. Sox, and W.B. Nesbitt. 1976. Cell wall bound nitrophenylglycosidase of tomato fruits. J. Amer. Soc. Hort. Sci. 101: $397-400$.

Promyou, S., S. Ketsa, and W.G. van Doorn. 2008. Hot water treatments delay cold-induced banana peel blackening. Postharvest Biol. Technol. 48:132-138.

Rugkong, A., R. McQuinn, J.J. Giovannoni, J.K.C. Rose, and C.B. Watkins. 2011. Expression of ripening-related genes in cold-stored tomato fruit. Postharvest Biol. Technol. 61: $1-14$. 
Rugkong, A., J.K.C. Rose, S.J. Lee, J.J. Giovannoni, M. O'Neill, and C.B. Watkins. 2010. Cell wall metabolism in cold-stored tomato fruit. Postharvest Biol. Technol. 57:106-113.

Wang, B., J. Wang, H. Liang, J. Yi, J. Zhang, L. Lin, Y. Wu, X. Feng, J. Cao, and W. Jiang. 2008. Reduced chilling injury in mango fruit by 2-4-diclorophenoxyacetic acid and the antioxidant response. Postharvest Biol. Technol. 48: 172-181.

Watkins, C.B. 2006. The use of 1-methylcyclopropene (1-MCP) on fruits and vegetables. Biotechnol. Adv. 24:389-409.
Woolf, A.B., C.B. Watkins, J.H. Bowen, L. Michael, J.H. Maindonald, and I.B. Ferguson. 1995. Reducing external chilling injury in stored 'Hass' avocados with dry heat treatments. J. Amer. Soc. Hort. Sci. 120:1050-1056.

Yimyong, S., T.U. Datsenka, A.K. Handa, and K. Seraypheap. 2011. Hot water treatment delays ripening-associated metabolic shift in 'Okrong' mango fruit during storage. J. Amer. Soc. Hort. Sci. 136:441-451

Zaharah, S.S. and Z. Singh. 2011. Postharvest nitric oxide fumigation alleviates chilling injury, delays fruit ripening and maintains quality in cold-stored 'Kensington Pride' mango. Postharvest Biol. Technol. 60:202-210.

Zheng, X., G. Jing, Y. Liu, T. Jiang, Y. Jiang, and J. Li. 2012. Expression of expansin gene,

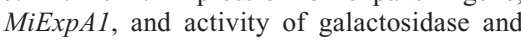
polygalacturonase in mango fruit as affected by oxalic acid during storage at room temperature. Food Chem. 132:849-854.

Zhou, Z., W. Jiang, J. Cao, Y. Zhou, and Y. Gu. 2006. Effect of cold-shock treatment on chilling injury in mango (Mangifera indica L. cv Isquo Wachengrsquo) fruit. J. Sci. Food Agr. 86:2458-2462. 